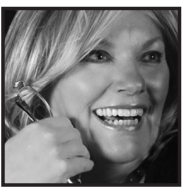

\title{
Capturing the Processes of Our Transformative Learning in a Transdisciplinary Research Course
}

Janet C. Richards, University of South Florida

\begin{abstract}
Transdisciplinary scholarship has experienced a renaissance in higher education. Yet, little research has captured transformations in students' viewpoints as they collaborate in transdisciplinary courses to consider solutions to complex societal problems. In this narrative inquiry, I chronicled my doctoral students' perspectives and my thinking in a Transdisciplinary Research class in which students attempted to unravel the social justice dilemma of escalating economic disparities between rich and poor citizens in the United States. I believe knowledge is socially constructed. Therefore, student collaboration and sharing of their reflective stances were integral to the curriculum.
\end{abstract}

"Although the notion of transformative learning points to a desirable destination for educational endeavors, the difficulty in the journey is often neglected" (Mälkki \& Green, 2014, p. 5)

early 40 percent of university faculty recently reported they have
taught a course in which students contemplate why and how to span
discipline boundaries to solve multifaceted societal and scientific issues in transdisciplinary courses (Gray, 2008). However, participants' experiences in transdisciplinary courses remain unknown despite insights that might emerge from detailed explorations of transdisciplinary educational arenas (Derry, 2005). In this narrative inquiry, I captured my doctoral students' learning processes in a transdisciplinary research class in which I followed dimensions of transformative learning tenets. I also documented transformative changes in students' frames of reference, and highlighted my shortcomings as a transformative learning educator. 


\section{A Brief Review of Transdisciplinary Research}

Transdisciplinary inquiries integrate and synthesize content, theory, and methodology from diverse areas of study that will answer designated research questions framed according "to life-world problems rather than disciplines" (Kueffer, Hirsch Hadorn, Bammer, van Kerkhoff, \& Pohl, 2007, p. 22). Moreover, scholars from relevant fields share resources and engage equitably in research with knowledgeable practitioners and stakeholders to achieve a common goal (Hirsch Hadorn et al., 2008). For example, a transdisciplinary sociologist interested in discerning the effects of poverty on impoverished community members would not engage in a study by herself. Rather, she would invite community residents (i.e., stakeholders) as well as scholars and practitioners in germane disciplines to share their insights and help shape the research agenda. ${ }^{1}$

\section{My Pedagogical Orientation}

Some research indicates an instructor's educational philosophy and related teaching approaches may produce more beneficial outcomes for students in transdisciplinary programs of study than course content (Newell, 1994). Therefore, I briefly describe myself and my pedagogical orientation and teaching dispositions relevant to this inquiry.

I am a white, middle-aged, middle-class, female professor at a top-tier, researchone university. I value adult learners' experiences and talents, and work to position the instructor-student power dynamics so we are all co-learners. I believe knowledge is socially constructed, and active participation is an integral component to students' attainment of understanding (Wenger, 2006). I am philosophically disposed toward transformative learning theory "as a powerful image for understanding how adults learn" (Dirkx, 1998, p. 1). Thus, I encourage student collaboration, limit lectures, promote a problem-based and cooperative learning environment, and create opportunities for students to become personally involved with their scholarship by taking charge of their learning. I also work to foster a sense of cohesive, democratic solidarity and encourage students to question, become aware and critical of their assumptions, and feel free to take risks and offer their opinions. This style of teaching is often not an easy way to teach. "It means asking yourself, am I willing to transform in the process of helping my students transform?" (Taylor, 2008, p. 13). I learned through this inquiry it also means asking myself, 
How can I support and challenge my students as they experience discomfort related to navigating a transformative learning agenda? In what ways can I encourage students to become critical of their assumptions? What might I discover about my pedagogy as a professor who adheres to tenets of transformative learning in a transdisciplinary research course? (from my journal notes)

\section{Confronting My Mistakes}

Research suggests working on complex, authentic problems situated beyond the university environment, such as in transdisciplinary courses, may enhance student teaching (Lattuca, Voigt, \& Fath, 2004). Therefore, in the spirit of transparency I maintain throughout this inquiry, I must acknowledge that the first time I taught a transdisciplinary research course, I did not sufficiently appreciate the value of authentic problem solving as it pertains to research that crosses discipline boundaries. As a result, I neglected to connect course content to a contemporary societal issue. Consequently, my students had difficulties understanding transdisciplinary theory.

Thus, the second time I taught the course Transdisciplinary Research (described in this paper), I was determined to ensure the curriculum was authentically issue-driven. I sought to include a strong, pragmatic, problem-solving, group effort component to our work that would supply a foundation for our reflexive thinking and meaning making. I envisioned students would collaborate to identify a social problem and then work to solve it. Yet, before meeting my students, I became concerned about their capabilities to choose a worthwhile problem to study without my substantial input and guidance. Consequently, I made another error and decided to link chronic disparities in wealth distribution in the United States as a salient foundation for our communal research. In hindsight, following tenets of transdisciplinarity, I should have offered my students the opportunity to choose and own their problem to investigate. A critical defining characteristic of transdisciplinarity is the joint inclusion of stakeholders (in this case, my students) in delineating research objectives and strategies (see King, 2009).

Another concern I did not anticipate was that all 11 students in the class matriculated in related educational disciplines, in contrast to genuine transdisciplinary research that intersects scholars from diverse sources and includes knowledgeable practitioners and stakeholders. We were hampered by our homogeneous educational knowledge base and worldview. 


\section{My Reasons for Conducting the Study}

As I prepared to teach the course, I turned to the extant literature and discovered there is a need for inquiries that chart transdisciplinary processes from students' firstperson points of view in 21st century learning communities (Vess \& Linkon, 2002). In particular, research needs to explore the connections among transdisciplinary "theory, pedagogy, course enactment, and student perceptions" (p. 96).

I also wondered how my students might reflect about course content and communicate their developing understandings and quandaries throughout the semester. Additionally, I wanted to add my own ongoing challenges, perceptions, and thinking to the study to inform my professional growth and provide opportunities for me to fine-tune future transdisciplinary course activities. Moreover, as a transformative learning theory proponent, I sought to document in what ways my students might develop the capacity to reflect critically on the lenses they used "to filter, and interpret the world" (Belenky \& Stanton, 2000, p. 1). I also wanted to provide insights to faculty who wished to design and offer quality transdisciplinary learning environments.

\section{The Inquiry}

At the beginning of the semester, after receiving Institutional Review Board approval, I invited my 11 doctoral students (two men, nine women, all Caucasian) to engage with me in a study about our involvement and experiences in the class as we considered problems and solutions related to poverty in the United States. Ten were from middle-class American environments. Ben ${ }^{2}$ had immigrated on his own to the United States from former communist-dominated Hungary, where he and his family had endured economic hardships and hunger. None of the 11 students had previously considered the social and political factors related to economic inequity in the United States. All of the students decided to participate in the study. I had few reservations about students contributing candid thoughts and opinions.

\section{Literatures Informing the Inquiry}

I relied on interconnected literatures that provide perspectives on collegial learning to undergird the inquiry and guide my analytic lens. The theories illustrate how adults construct knowledge as they work jointly in social environments. 
The first prototype, Communities of Practice, provides a useful perspective on knowing and learning. Lave and Wenger (1991) define Communities of Practice as "groups of people who share a concern or a passion for something they learn and do and learn how to do it better as they interact regularly" (p. 98). Membership in a Community of Practice implies a combination of three elements: (1) a commitment to a domain, or area of interest (in this case, transdisciplinarity and social justice as it pertains to economic disparity between rich and poor in the United States); (2) a community engaged in actions and discussions pertinent to a domain (i.e., our class); and (3) shared experiences, stories, and ways of figuring out dilemmas and quandaries (Wenger, 1998).

In the second model, Situated Learning Theory (Lave \& Wenger, 1991), learning takes a broad meaning and is viewed as a fundamental dimension of social participation. Situated Learning Theory explains as individuals participate in social practices within a social organization, the organization shapes their understandings. In turn, as individuals gain new understandings, their newly acquired knowledge shapes the thinking and processes of the social organization to which they belong (Bleiler, 2014). Relevant to this study also is that situated learning theory asks in what ways learning facilitators (e.g., me, as the instructor) change as they interact with co-learners and strive to promote learning.

Furthermore, Distributed Intelligence Theories offer support for this inquiry. Although creative individuals are often thought of as working in isolation, scholars believe much of human intelligence and creativity arises from synergistic interaction and collaboration with individuals from different disciplines and ways of thinking (Csikszentmihalyi, 1996).

\section{Choosing Narrative}

My reasoning for choosing narrative follows. In this inquiry, I assumed three roles: teacher, researcher, and study participant in which I placed myself alongside my students as we journeyed together through the course. Thus, my views and perceptions were part of the data I collected. As Clandinin (2013) comments, narratives make meaning of participants' stories and those of researchers as well. In addition, Connelly and Clandinin (1990) point out "researchers need to tell their stories too" (p. 12).

I also selected narrative inquiry because of its capacity to preserve participants' authentic voices and, reveal their thinking, confusions, hopes, relationships, and ways 
they interpret the world (Brooks, Arnold, \& Brooks, 2013). Without question, the research reported here was dependent on my students' ideas and dilemmas as they pondered, discussed, and applied their developing understanding of transdisciplinary research in an attempt to find solutions to economic inequity among citizens in the United States.

In addition, I turned to narrative because as narrative is broadly defined it, "come[s] in many forms and sizes" (Riessman, 2008, p. 23), and portrays transformations over time (Savin-Baden \& Major, 2013). When I considered these notions, I realized my students' weekly e-mail reflections and in-class discussions, coupled with my thoughts and journal notes, embodied central dimensions of narrative.

\section{Determining Data to Include in the Study}

I must clarify in what ways I selected data (i.e., "field texts") to incorporate in this manuscript (what Clandinin and Huber, 2010, refer to as "research texts"). There is no doubt I was influenced by my biases as the professor of the course, my beliefs about teaching and learning, and my personal and professional experiences. Yet, I was mindful to choose students' e-mail stories, students' in-class dialogue, my thoughts during class, and notes from my journal I believed best portrayed the "truth" of our situated lives. I included data from four of the 11 study participants because their reflections particularly made clear how learning is a developmental process that evolves over time (i.e., temporally).

\section{Selecting an Approach to Analyze the Data}

The majority of narrativists believe "narratives do not speak for themselves" (Personal Narratives Group, 1989, p. 264). "People tell stories, but narratives come from the analysis of stories" (Frank, 2000, p. 4). The researcher's role is to interpret the stories to give voice to the storytellers (Frank, 2000). Recognizing there are multiple approaches for analyzing narrative field texts, after considerable reading, I decided to use Mezirow's Ten-Phase Hierarchical Framework of Change (2000) to interpret and make sense of the data (refer to the Appendix for a listing of Mezirow's 10-phase framework). Mezirow's paradigm categorizes a process in which individuals encounter a disorienting dilemma that causes them to question their currently held assumptions and, as a result, alter their frames of reference by moving through various stages 
of critical reflection (i.e., individuals work through their beliefs and assumptions "and assess their validity in the light of new experiences or knowledge," Cranton, 2002, p. 65). I particularly chose Mezirow's model because both critical reflection and social responsibility are paramount to Mezirow's framework and these constructs were also critical to our meaning making in the course.

Of interest is that the meaning imbedded in my students' discourse affirmed later conceptions of the process of transformative learning in which scholars concluded "the process does not always follow the exact sequence of phases but generally includes some variations of the identified phases" (Taylor, 2000, p. 290). Specifically, my students moved through earlier stages of transformation in a linear, but not step-by-step fashion as they tried to make their own interpretations and meaning. Only one student (Meg, who is highlighted in the next section of this paper) regressed to an earlier phase of the transformative process.

\section{Making the Data Visible}

\section{From My Notes After Class One}

As soon as I arrive home from class I receive e-mail reflections from students that indicate, not surprisingly, they are in the first stage of Mezirow's (2000) phases of Transformative Learning (experiencing a disconcerting dilemma). It is usually in confronting unknown ideas that one's previously held worldview becomes a disorienting problem. Prior to reading the syllabus, my students had not heard the term transdisciplinary and equated it with multidisciplinary and interdisciplinary teaching. They also were unsure about social justice in terms of wealth distribution, opportunities, and privileges within a society. Furthermore, they didn't question why we were going to study economic inequities in the United States. I know they are anxious about the course, which makes me anxious as well. In fact, anxiety among faculty who support students in transformative learning courses is well known (Mälkki \& Green, 2014). One reason is that facilitating and supporting the transformations of insecure students who feel challenged and out of their comfort zone is demanding. Students' prior beliefs are tested as they struggle to adopt new perspectives. But, "an educator who is afraid of the dissolution of [students'] established beliefs will find it difficult to accompany students on their journey" (p. 10). Therefore, I cannot be afraid. I can't allow myself to get alarmed about my students' apprehensions. I know their established understandings about 
single-person research have already started to dissolve and I have to accompany and support them on this journey of creating new possibilities and meaning. I can't help myself though-I worry as I read the following e-mail reflections. Will this semester work out?

\section{A Student's E-mail Reflections After Class One}

As I expected, the e-mail reflections from all 11 students indicated they were in Phase 1, Experiencing a Disconcerting Dilemma as delineated by Mezirow (2000). The following messages illuminate some students' confusions.

Diana (an elementary teacher). Her message permeates with vulnerability and uncertainty. I felt a bit lost during and after our class. As to having a clear definition for what transdisciplinary research is...well I don't exactly have one yet. What I do know is it seems similar to multimodal and multidisciplinary teaching. Is it? Maybe it isn't? It seems to be a ripe field for philosophical and collaboration and that in order to be transdisciplinary it should address a problem.

Beth (a verbal, secondary English teacher). Beth, too, admits her confusion. But it is interesting to note she accepts responsibility for learning.

Can you use the term, "transdisciplinary experiences"? Have I used it within the correct context? Just writing my thoughts about class tonight forces me to realize how much I need to learn in order to be write about transdisciplinary in a cognizant manner. I need to read a lot and reflect.

From my notes. Beth's reflection (see above) makes me think about the connection between shifts in perspective and the necessary simultaneous extension of students' language. Discourse expands language and fosters new thinking that can be "reflected upon, and communicated" (Meyer \& Land, 2005, p. 374). In other words, you can't think about something or share your thinking with others unless you have the language to think about it. Therefore, it's clear that discussion is paramount to my students' acquisition of new vocabulary and ideas about economic inequity in the United States.

\section{From My Notes After Class Two}

My students' questions tonight about trandisciplinary research show me they have a long way to go to understand what this class is about. I might be (no, I am) 
pushing them too much to take it all in and then engage in trandisciplinary research to figure out solutions to economic inequity in the United States. Perhaps I should slow down. After all, this is only the beginning of the course. Tonight I also made another mistake-after providing demographic information about 45.3 million Americans living in poverty (United States Census Bureau, 2013), I posed a problem that focused on a community of people in low-income housing near the university: "How might we as citizens provide help to the citizens living in Hayes Village?" (a pseudonym). That's where we quickly learned you cannot solve a transdisciplinary research problem unless you know what stakeholders consider problematic. So, we learned something. But we were also stuck because, as a group of transdisciplinaryresearch researchers, we needed to know where to discover information that would lead us to possible solutions to the problem and we did not have any reference materials at hand except the Internet-no stakeholders-historical artifacts, readings, multi-discipline experiences, nothing. That's my fault. And students are understandably uneasy with the unknown. Here's another concern. I now (just now!) realize engaging in transdisciplinary research to try to find solutions to wealth disparity in the United States might be way too big a problem for us to handle in 15 weeks. We are not economics and political experts. To engage in authentic transdisciplinary research it seems we need to have scholars in other disciplines in our class. I just located a great CNN report (Sutter, 2013) on how to lower the richpoor gap. This should prove helpful.

Ben in class three (a former citizen of Soviet-dominated Hungary, a free spirit, a community gardener, highly artistic). Stage five. A call for action. "Why do we sit talking about transdisciplinary research? Why are we not helping humanity? We could start a rooftop garden on top of the Education Building and give the vegetables to people who are hungry."

\section{From My Notes After Class Three}

After our third class students began to reflect somewhat. I feel good about this. Ben even made a seismic jump to Stage Five (Mezirow, 2000) and calls for action. Ben had a great idea. It makes sense that his prior economic hardships and hunger in communist Hungary might influence his reasoning about giving food to those in poverty situations. To a large extent, all of us are affected by our backgrounds. Much of what we know and believe, "our values and our feelings, depends on the context - biographical, historical, cultural- in which they are embedded" (p. 3). But we need to think things through as transdisciplinary researchers. Shouldn't we involve the stakeholders from the get-go? What do stakeholders think they need? And is a 
rooftop garden feasible? Are we being overly altruistic and also considering "them" and "us"? I think so. Diana also wants to explore options for action.

Diana (e-mail after class 3). Stage five. A call for action. Compared to her initial reflection, Diana's timidity has decreased. Yet, she still wants to know what I think.

Ben just mentioned something great tonight-a rooftop garden at our College of Education. Why couldn't we invite some other departments to join us in this project? We could use Ben's knowledge of organic gardening, someone from the science department, etc. To me, hunger is a major problem and it is unfortunately a problem near our college. What do you think? How might we be a part of this?

\section{From My Notes After Class Six}

It seems "Stage Five: A Call for Action" is where all of my students experience their comfort level. Mälkki and Lindblom-Ylänne (2012) explain we all have a natural tendency to remain at our comfort level and resist moving forward to a new level of transformational learning. Learners can get stalled at any phase. "This is especially true at the beginning of a transformation with its threat to long-established sense of order" (Mezirow, 2000, p. xii). Mezirow's idea helps clarify why my students are at an impasse. They are still in the early stages of the course and they're not yet ready to cross the threshold and move on to a later stage of transformation because (perhaps) of the conceptual difficulty of trying to understand transdisciplinary and social justice tenets related to poverty at the same time and in one semester. Or (and I need to think about this more), I have not supported them sufficiently. I'm also concerned the topic of economic inequality between rich and poor in the United States is not particularly conducive to transformative learning because we are separated (too far removed) from what are trying to grasp. We need to get out in the community surrounding the university. The literature refers to this impasse-this block to students' progress as liminality — confusion, resisting, disoriented because "leaving the cocoon of one's founding premises throws one into an existential turmoil" (Mälkki \& Green, 2014, p. 18). If the transformative process remains static at some point, which is relevant to this study (i.e., individuals remain in a state of disequilibrium), "it is likely due to the difficulties experienced during a transitional phase when one is in a state between two different meaning frameworks letting go of the prevailing but not yet achieving the potential one" (Meyer, Land, \& Baillie, 2010, p. 8; i.e., liminality). Emerging from the liminality experience and moving forward in suppositions often takes substantial time for one's conceptual understanding to catch up to tenuous new premises (Mälkki \& Green, 2014). 
I need to try to understand what is posing my students' obstacles to transformation. Transformative theorists note the importance of optimum conditions for supporting students' transformative learning. Am I not creating optimum conditions? When Ben asks, "What are out options?" Shouldn't I address his question? Yet, it would do no good for me to lecture and supply my students with a template of what they need to learn. True, a cognitive map security blanket would provide them with a sense of safety, but would not serve to as a substitute for transformation (see Mälkki \& Green, 2014). My students need to make their own journey of transformation. I just need to remember as transformative learning scholar, Kathy King, told me (personal communication, 2015) "reframing values and beliefs takes time - much more than a semester."

Meg (in class eight). Stage seven. Acquisition of knowledge and skills for implementing one's plan. Meg is a full-time doctoral student who is thoughtful and reflective. She offers some insights about theoretical underpinnings of action.

Why are we sitting here talking instead of going out and doing? I think the question is a good one, and I've spent some time thinking about it today. Transdisciplinarity is abstract. But, focusing solely on the "going out and doing" aspect of transdisciplinarity would, I think, miss an important part of the process, which is a focus on the theoretical underpinnings that move our practice to a very specific type of praxis. What do we need to know?

My thoughts in class. Oh this is good. Meg gets it. She's moved forward in her thinking. Will the other students jump on board? But then I remember something. We still haven't touched on solutions to the economic gaps between rich and poor in the United States. In fact, we haven't even touched the surface of the rich-poor gap. Except for Meg, students are still stuck in their preoccupation with a call for action. It is my error.

\section{From My Notes After Class Nine}

Today I experienced an unexpected, shocking episode of transformative learning. Different from a stepwise, gradual progression of transformation, Mezirow (2000) refers to this intense insight l experienced as epochal (i.e., significant, powerful, and sudden). Specifically, my subconsciously and unexamined views about people in poverty in the United States were challenged. I just read a book titled Reaching and Teaching Students in Poverty: Strategies for Erasing the Opportunity Gap authored by Paul Gorski (2013) who teaches at George Mason University. Here's what struck 
me. Are we trying to "fix" people of poverty by "helping" them? By considering what we want to give to people who we consider as disadvantaged don't we actually hurt them? Do we have a "Savior Syndrome"? These ideas are now in the forefront of my thinking. Aren't we taking a deficit view of people who live in poverty? By that I mean we do not need to "fix" people in poverty circumstances. We need to alter social and political conditions to enable people from low socioeconomic circumstances to empower themselves. They need better access to education, health care, and jobs. Why couldn't I have consciously understood this early on so I could bring these ideas to my students??? I could have at least shared my views. I should have read this book prior to teaching the class. Now I understand what Taylor (2008) means when he presents this statement to transformative learning facilitators: "It means asking yourself, am I willing to transform in the process of helping my students transform?" (p. 13). I am embarrassed to say I should have known better. My efforts need to include helping students acquire the skills necessary for understanding the literature about poverty. It seems as I teach this course I am learning to teach this course.

\section{From My Notes After Class 10}

I brought Paul Gorski's (2013) ideas to the class tonight. Students were at a cognitive/emotional place where they could understand and begin to internalize these concepts. So-all is not lost-except now I feel distraught-Students' continued resistance, to explore more valid assumptions beyond a "Call to Action" were more than partially caused by me (another mistake). Reviewing my notes shows we did not do a sufficient amount of research needed this semester to move forward beyond a stereotypical deficit view of people in poverty. For example, I think we all needed to read and discuss a chapter I just found: Social justice and the fifth force: Theories and concepts (Chung \& Bemak, 2011).

\section{From My Notes After Classes 11-13}

Nothing new has happened with students' shifts forward. We have great conversations, the discourse is always interesting, and students continue to question, ponder, and actively discuss, but they haven't reached any new milestones. It is clear I have not set up a process in which learners become more aware of the underlying causes of their beliefs. They have not experienced a change in perspectives. I know this now. I need to question my students and assign readings to challenge their assumptions. I am teaching this course again for the third time in the fall. I will do better. 


\section{From My Notes After Class 14}

It's the end of the semester and students [see reflections below] are doing a great job of summarizing their thinking. They have not yet experienced deep, structural shifts in their beliefs about how to alleviate economic inequality in the United States. They have not yet seriously considered the relationship of power associated with race, class, gender, and socioeconomic status. And, except for Meg they have not moved beyond Stage Five 5 as delineated on Mezirow's (2000) framework. However, without my prompting, they have begun to take stock of their learning in the course. They appear to be summing up what they have learned not only for me and for other students in our class, but also for themselves.

Diana (e-mail reflection). Diana's reflection shows she has learned a lot about transdisciplinary research. She astutely says this type of research is influenced by individuals' abilities to solve problems. She still questions herself: "Am I doing this right?"

The first few weeks of class I was confusing interdisciplinary with what I now know as transdisciplinary. I am very much interested in the notion of transdisciplinary research. To me, it just makes sense you would want to have multiple fields involved in an effort to "solve various problems." Having those multiple fields/disciplines would allow the team a well-rounded way of thinking about a solution. It seems many of the efforts that have been made to address issues in for example, education, have been short-[sighted] and quick fixes.... I wonder if it is because the scope of knowledge is limited based on the individual's abilities to "solve various problems". I'm not sure if that makes any sense. I'm just going with what I'm thinking. Does any of that make sense? Am I doing this right?

From my notes. Oh-oh. Meg's closing reflection (see below) indicates despite her earlier move forward in her suppositions (see Meg's reflection for class eight and compare it with her reflection below), she is stuck in the threshold of liminality. She also critically questions the validity of solving social justice issues.

Meg (e-mail reflection). Meg continues to think about the importance of stakeholders in transdisciplinary research. She also reveals she has reverted back to a "we-them" view.

I continue to make personal connections with transdisciplinarity. I ponder ways in which researchers and members of diverse communities could potentially merge their various understandings of the world in order to transform understanding of complex problems. As trandisciplinary researchers, before we attempt to find 
solutions to a problem our guiding questions might be: What are the needs for change? What are stakeholders' beliefs and perceptions about the need for change and what might we do to help them move forward? Is the need for change in this particular case doable? But, Dr. R., I wonder if we can really 'solve' issues of social justice. Are we naive to think we can, or can't?

Beth (e-mail reflection). Beth's summary shows she continues to focus on two basic, uncomplicated, straightforward ideas we discussed at the beginning of the semester: (a) Do not assume to know what people in poverty need; and (b) As transdisciplinarians, we need to remember to learn from scholars in other pertinent disciplines.

As we move into the final weeks of our class I find myself reflecting on what I will transfer to my professional practice. While I don't anticipate finding myself on a panel of transdisciplinary researchers in the near future, the schema and experiences I developed this semester will provide a holistic perspective of social justice issues. My big take away is we can't assume to know what a population needs. We must endeavor to learn their perspective in order to adequately address issues of social justice. Additionally, we must be willing to adapt our perspective based upon what we have learned from researchers in other disciplines.

\section{From My Notes After Our Last Class}

The semester is over and it's time to make sense of what I learned through this inquiry. If we want to know ourselves and gain insight into the meaning of our experiences, then "we must come to know our own story" (McAdams, 1993, p. 1). Thus, I share the Limitations of the Inquiry below followed by the meaning I gleaned from the research.

\section{Limitations}

There are several limitations of the inquiry I must address prior to sharing the closing segment of our "story." An important consideration is that researcher subjectivity is a central component of the qualitative research process. What I saw in the data was influenced by my life experiences; my role as an involved, committed instructor of a transdisciplinary research course; who I am as a transformative learning educator; and my subconsciously held personal and professional biases. Feminist perspectives also acknowledge the transactional nature of qualitative work and the challenges, 
limitations, and presumption of interpreting others' points of view and realities mediated by one's personal experiences and perceptions (Bahar, 1993; Florio-Ruane, 2001). Moreover, hermeneutic considerations "indicate that the same text can be read [and interpreted] in a number of different ways" (Tappan \& Brown, 1992, p. 186). Others might draw conclusions different from mine.

Another issue pertains to my students' willingness and abilities to disclose their "truths" through e-mail and in-class conversations. Since I was their instructor who awarded final grades, they may have cautiously monitored what they chose to share with me. A possibility also exists that some students might have had difficulty communicating their thoughts through e-mail or in-class discussions. Therefore, they may not have fully expressed their opinions and questions.

\section{Making Meaning}

Writing the finale of our "story" crystallized my convictions that narrative -a methodological approach not used previously in either transdisciplinary or transformative learning research-enabled me to document our experiences and illuminate our concerns and struggles throughout the semester. Our e-mail reflections, thoughts, and comments revealed our worries and confusions and our optimism and uncertainties - the "truths" of our situated lives. Narrative viewed as collaboration between researcher and study participants also permitted me to be "present" with my students (Clandinin \& Connelly, 2000; Noddings, 1984). That is, narrative inquiry created a platform that permitted our voices and vulnerabilities to be heard as we (students and teacher) endeavored to make our understandings clearer.

Another consideration is there is no doubt the research has practical utility. The inquiry informs those who teach transdisciplinary research courses, in which students contemplate why and how to span discipline boundaries, to solve multifaceted societal and scientific issues. The study also sheds light on students' thinking in a doctoral class in which transformative learning philosophy guided instruction. In addition, the data show it is possible for those in transformative learning environments to talk and write about their developmental journeys, including their confusions, skepticisms, and assumptions. Therefore, the inquiry adds to our understanding of the complex nature of learning and the crucial connection between critical reflections and transformations in students' meaning perspectives. This is no small feat. As Harbecke (2012) notes, "Even for educators, who understand that transformation is a profound force in learning, 
trying to introduce it in an actual learning experience is like trying to capture lightning in a bottle" (Para. 2).

An additional benefit is that the study highlighted transformation as both a personal and collaborative journey that begins with a disorienting dilemma, consists of starts, stops, twists, turns, anxiety, and confusions and is influenced by one's affective dimensions and "meaning perspectives acquired passively during childhood and youth" (Cooper, n.d., Para. 5). Therefore, this work offers further validation of Mezirow's (2000) theory of learning as transformation.

Certainly, the research helped me examine, reexamine, contemplate, and address my shortcomings as a transformative learning educator. I was not surprised the inquiry uncovered my inadequacies as an instructor with a transformative teaching and learning philosophy. But I was taken aback when I encountered the extent of my pedagogical flaws, which I shared earlier. Making sense of one's teaching practices is often not easy, especially through a public forum. Yet, acknowledging my pedagogical ineptitude helped me see my teaching in new ways and I conclude I have a lot to achieve the next time I teach Transdisciplinary Research. As the noted French philosopher Paul-Michel Foucault observed, the importance of truth telling in public to serve the common good (i.e., parrhesia) is central, not only to educational improvement, but also crucial to the care of the self (Peters, 2003).

A final and most important discovery of this study is that I learned how valiant, indomitable, and willing, my doctoral students were to continue to struggle through the transformative process as they endeavored to articulate their emerging understandings about transdisciplinary research. Some learning theorists believe students in transformative learning classes may simply "give instructors what they want. That is, students only appear to engage with new ideas" (Taylor, 2000, p. 159). But I am confident my students wrote and told their "truths." Although they were unable to overcome their liminality (i.e., they remained is a state of disequilibrium until the end of the course), they never gave up their quest to explore alternative frameworks about transdisciplinary research despite experiencing cognitive dissonance. I am grateful they allowed me into their lived experiences. 


\section{Notes}

1. For additional information about transdisciplinary research, refer to Derry \& Fisher, 2005, and Hoffmann-Riem et al., 2008.

2. All doctoral student names are pseudonyms.

\section{References}

Bahar, R. (1993). Translated woman: Crossing the border with Esperanza's story. Boston: Beacon.

Belenky, M. F., \& Stanton, A. V. (2000). Inequality, development, and connected knowing. Learning as transformation: Critical perspectives on a theory in progress, 71-102.

Bleiler, S. K. (2014). Increasing awareness of practice through interaction across communities: The lived experiences of a mathematician and mathematics teacher educator. Journal of Mathematics Teacher Education, 18(3), 231-252.

Brooks, J.S., Arnold, W.N., \& Brooks, M.C. (2013). Educational leadership and racism: Secondgeneration segregation in an urban high school. Teachers College Record, 115, 1-27.

Chung, R. C. Y., \& Bemak, F. P. (2011). Social justice counseling: The next steps beyond multiculturalism. Thousand Oaks, CA: Sage.

Clandinin, D., \& Huber, J. (2010). Narrative inquiry. In B. McGaw, E. Baker, \& P. Peterson (Eds.), International encyclopedia of education (3rd ed.), (pp. 436-441). New York: Elsevier.

Clandinin, D. J. (2013). Engaging in narrative inquiry. Walnut Creek, CA: Left Coast Press.

Clandinin, D. J., \& Connelly, F. M. (2000). Narrative inquiry: Experience and story in qualitative research. San Francisco: Jossey-Bass.

Connelly, F. M., \& Clandinin, D. J. (1990). Stories of experience and narrative inquiry. Educational Researcher, 19(5), 2-14.
Cooper, S. (n.d.). Jack Mezirow: Transformational Learning. Retrieved from http://www.life circles-inc.com/Learningtheories/humanist/ mezirow.html

Cranton, P. (2002). Teaching for transformation. New Directions for Adult and Continuing Education, 2002(93), 63-72.

Csikszentmihalyi, M. (1996). Creativity: Flow and the psychology of discovery and invention. New York: HarperCollins Publishers.

Derry, S. J. (2005). STEP as a case of theory-based web course design. In A. O'Donnell \& C. Hmelo-Silver (Eds.), Collaboration, reasoning and technology. Mahwah, NJ: Lawrence Erlbaum Associates.

Derry, S. J., \& Fisher, G. (2005). Toward a model and theory for transdisciplinary graduate education. Paper presented in the symposium, Socio-technical Design for Lifelong Learning: A Crucial Role for Graduate Education, presented at the Annual Meeting of the American Educational Research Association, Montreal, Canada.

Dirkx, J. M. (1998). Transformative learning theory in the practice of adult education: An overview. PAACE Journal of Lifelong Learning, 7, 1-14.

Florio-Ruane, S. (2001). Teacher education and the cultural imagination: Autobiography, conversation, and narrative. Rotterdam, Netherlands: Routledge.

Frank, A. W. (2000). The standpoint of storyteller. Qualitative Health Research, 10(3), 354-365. 
Gorski, P. (2013). Reaching and teaching students in poverty: Strategies for erasing the opportunity gap. New York: Teachers College Press.

Gray, B. (2008). Enhancing transdisciplinary research through collaborative leadership. Retrieved from http://www.ncbi.nlm.nih. gov/pmc/articles/PMC2542584/ doi:10.1016/ j.amepre.2008.03.037

Harbecke, D. (2012). Following Mezirow: A roadmap through transformative learning. Retrieved from http://rutraining. org/2012/10/08/following-mezirow-a-road map-through-transformative-learning/

Hirsch Hadorn, G., Biber-Klemm, S., Grossenbacher-Mansuy, W., HoffmannRiem, H., Joye, D., Pohl, C., et al. (2008). The emergence of transdisciplinarity as a form of research. In G. Hirsch Hadorn et al. (Eds.). Handbook of transdisciplinary research, (pp. 19-39). Rotterdam, Netherlands: Springer. doi:10.1007/978-1-4020-6699-3_2

Hoffmann-Riem, H., Biber-Klemm, S., Grossenbacher-Mansuy, W., Hirsch Hadorn, G., Dominique J., Pohl, C., et al. (Eds.). (2008). Idea of the handbook. Handbook of transdisciplinary research, (pp. 3-17). Zurich, Switzerland: Springer.

King, K. P. (2009). Handbook of evolving research approaches in transformative learning: The Learning Activities Survey (10th anniversary edition). Series: Adult education special topics: Theory, research and practice in lifelong learning. Charlotte, NC: Information Age Publishing, Inc.

Kueffer, C., Hirsch Hadorn, G., Bammer, G., van Kerkhoff, L., \& Pohl, C. (2007). Towards a publication culture in transdisciplinary research. GAIA, 16(1), 22-26.

Lattuca, L., Voigt, L., \& Fath, K. (2004). Does interdisciplinarity promote learning? Theoretical support and researchable questions. The Review of Higher Education, 28(1), 23-48.

Lave, J., \& Wenger, E. (1991). Situated learning: Legitimate peripheral participation. Cambridge, United Kingdom: Cambridge University Press.
Mälkki, K., \& Green, L. (2014). Navigational aids the phenomenology of transformative learning. Journal of Transformative Education, 12(1), 5-24.

Mälkki, K., \& Lindblom-Ylänne, S. (2012). From reflection to action? Barriers and bridges between higher education teachers' thoughts and actions. Studies in Higher Education, 37(1), 33-50.

McAdams, D. (1993). The stories we live by: Personal myths and the making of the self. New York: Morrow.

Meyer, J. H., \& Land, R. (2005). Threshold concepts and troublesome knowledge (2): Epistemological considerations and a conceptual framework for teaching and learning. Higher Education, 49(3), 373-388.

Meyer, J. H., Land, R., \& Baillie, C. (Eds.). (2010). Threshold concepts and transformational learning. Rotterdam, Netherlands: Sense Publishers.

Mezirow, J. (2000). Learning to think like an adult: Core concepts of transformation theory. In J. Mezirow et al. (Eds.). Learning as transformation: Critical perspectives on a theory in progress, (pp. 3-33). San Francisco: Jossey-Bass.

Newell, W. H. (1994). Designing interdisciplinary courses. In J. Klein \& W. Doty (Eds.). New directions for teaching and learning, (pp. 35-51). San Francisco: Jossey-Bass.

Noddings, N. (1984). Caring, a feminine approach to ethics \& moral education. Berkeley, CA: University of California Press.

Personal Narratives Group. (1989). Truths. In Personal Narratives Group (Eds.). Interpreting women's lives: Feminist theory and personal narratives. Bloomington, IN: Indiana University Press.

Peters, M. (2003). Truth-telling as an educational practice of the self: Foucault, Parrhesia and the ethics of subjectivity. Oxford Review of Education, 29(2), 207-223.

Riessman, C. K. (2008). Narrative methods for the human sciences. Thousand Oaks, CA: Sage.

Savin-Baden, M., \& Major, C. H. (2013). Qualitative research: The essential guide to theory and practice. New York: Routledge. 
Sutter, J. D. (2013). 7 ways to narrow the richpoor gap [video]. Retrieved from http:// www.cnn.com/2013/10/29/opinion/suttersolutions-income-inequality/

Tappan, M.B., \&Brown, L. M. (1992). Hermeneutics and developmental psychology: Toward an ethic of interpretation. The Role of Values in Psychology and Human Development, 105-130.

Taylor, E. W. (2000). Analyzing research on transformative learning theory. Learning as transformation: Critical perspectives on a theory in progress (pp. 285-328).

Taylor, E. W. (2008). Transformative learning theory. New Directions for Adult and Continuing Education, 2008(119), 5-15.

United States Census Bureau. (2013). Income and poverty in the United States. Retrieved from http://www.census.gov/hhes/www/ poverty/data/incpovhlth/2013/index.html
Vess, D., \& Linkon, S. (2002). Navigating the interdisciplinary archipelago: The scholarship of interdisciplinary teaching and learning. In M.T. Huber, \& S. P. Morreale, (Eds.). Disciplinary styles in the scholarship of teaching and learning: Exploring common ground, (pp. 87-106). Merrifield, VA: AAHE Publications.

Wenger, E. (1998). Communities of practice: Learning, meaning, and identity. Cambridge, United Kingdom: Cambridge University Press.

Wenger, E. (2006). Communities of practice: $A$ brief introduction. Retrieved from http:// wenger-trayner.com/

\section{APPENDIX}

\section{Mezirow's Ten Phases of Transformative Learning (2000)}

Phase 1. A disorienting dilemma

Phase 2. A self-examination with feelings of guilt or shame

Phase 3. A critical assessment of epistemic, sociocultural, or psychic assumptions

Phase 4. Recognition that one's discontent and the process of transformation are shared and that others have negotiated a similar change

Phase 5. Exploration of options for new roles, relationships, and actions

Phase 6. Planning of a course of action

Phase 7. Acquisition of knowledge and skills for implementing one's plans

Phase 8. Provisional trying of new roles

Phase 9. Building of competence and self-confidence in new roles and relationships

Phase 10. A reintegration into one's life on the basis of conditions dictated by one's perspective 


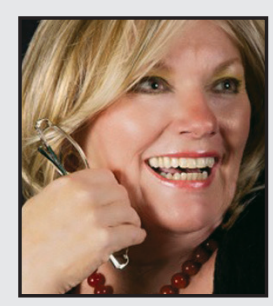

Janet C. Richards PhD is a Professor of Literacy and Qualitative Research in the Department of Teaching and Learning at the University of South Florida in Tampa. She served as a Visiting Scholar at the University of Victoria in British Columbia. She also was selected as a Literacy Scholar for the Reading and Writing for Critical Thinking initiative supported by the International Literacy Association. Richards is the Senior Editor of the journal, Literacy Practice and Research. Her latest book (as first editor) is entitled Social Justice, The Common Core, and Closing the Instructional Gap: Empowering Diverse Learners and Their Teachers. 